\title{
Geostatistical Distribution and Contamination Status of Heavy Metals in the Sediment of Perak River, Malaysia
}

\author{
Mohammed Abdus Salam ${ }^{1,2}{ }^{*}$, Shujit Chandra Paul ${ }^{3}$, Farrah Izzaty Shaari ${ }^{2}$, Aweng Eh Rak ${ }^{2}$, \\ Rozita Binti Ahmad ${ }^{4}\left(\right.$ ID and Wan Rashidah Kadir ${ }^{4}$ \\ 1 Department of Environmental Science and Disaster Management, Noakhali Science and Technology \\ University, Noakhali, Sonapur 3814, Bangladesh \\ 2 Faculty of Earth Science University, Jeli Campus, University Malaysia Kelantan, Jeli 17600, Malaysia; \\ farrah.izzaty@yahoo.com (F.I.S.); aweng@umk.edu.my (A.E.R.) \\ 3 Department of Applied Chemistry and Chemical Engineering, Noakhali Science and Technology University, \\ Noakhali, Sonapur 3814, Bangladesh; shujitchandrapaul@gmail.com \\ 4 Forest Biotechnology Division, Forest Research Institute Malaysia (FRIM), Kepong, Selangor 52109, \\ Malaysia; rozita@frim.gov.my (R.B.A.); rashidah@frim.gov.my (W.R.K.) \\ * Correspondence: s_salam1978@yahoo.com; Tel.: +88-0312-61433 or +88-01917-635348
}

Received: 21 March 2019; Accepted: 6 April 2019; Published: 10 April 2019

\begin{abstract}
Heavy metal pollution is one of the major environmental issues in recent decades owing to the rapid increase in urbanisation and industrialisation. Sediments usually act as sinks for heavy metals due to their complex physical and chemical adsorption mechanisms. In this study, heavy metals like lead $(\mathrm{Pb})$, Zinc $(\mathrm{Zn})$, Cadmium $(\mathrm{Cd})$, Copper $(\mathrm{Cu})$ and Iron $(\mathrm{Fe})$ in the surface sediment from 15 location (upstream and downstream) on the Perak River, Malaysia were investigated by means of inductively coupled plasma optical emission spectroscopy (ICP-OES). The geostatistical prediction map showed the range of $\mathrm{Pb}, \mathrm{Zn}, \mathrm{Cd}, \mathrm{Cu}$ and $\mathrm{Fe}$ concentration in upstream area was 14.56-27.0 $\mu \mathrm{g} / \mathrm{g}, 20-51.27 \mu \mathrm{g} / \mathrm{g}, 1.51-3.0 \mu \mathrm{g} / \mathrm{g}, 6.6-19.12 \mu \mathrm{g} / \mathrm{g}$ and $20.24-56.58 \%$, respectively, and in downstream areas was $27.6-60.76 \mu \mathrm{g} / \mathrm{g}, 49.04-160.5 \mu \mathrm{g} / \mathrm{g}, 2.77-4.02 \mu \mathrm{g} / \mathrm{g}, 9.82-59.99 \mu \mathrm{g} / \mathrm{g}$ and $31.34-39.5 \%$, respectively. Based on the enrichment factor and geoaccumulation index, $\mathrm{Cd}$ was found to be the most dominant pollutant in the study area. Pollution load index, sediment quality guidelines and sediment environmental toxicity quotient data showed that the downstream sediment was more polluted than the upstream sediment in the Perak River. The multivariate analysis showed that $\mathrm{Pb}, \mathrm{Zn}$ and $\mathrm{Cu}$ mainly originated from natural sources with minor contribution from human activities, whereas $\mathrm{Fe}$ and $\mathrm{Cd}$ originated from various industrial and agricultural activities along the studied area.
\end{abstract}

Keywords: heavy metals; sediment; risk assessment; geostatistical distribution; multivariate analysis; Perak river

\section{Introduction}

The pollution of the aquatic environment by heavy metals is a global problem because these metals are durable and most have toxic effects on living organisms when they are above certain concentrations [1,2]. Heavy metals produced by various activities such as chemical manufacturing, mining, municipal effluents and other anthropogenic activities are ultimately transferred to the aquatic environment [3]. Usually river sediment is a great adsorptive sink for heavy metals and the high concentrations in sediments can be lead to high concentration in living organisms through the food chain because of their nondegradable nature [4,5]. Besides bioaccumulation into the food chain, 
heavy metals that seep into sediments and can contaminate drinking water wells, as well as harm the consumers of that water [6]. Heavy metals are unable to be degraded either biologically or chemically hence they may be transported over long distances [2]. Considering their persistence and transferable properties, a distribution analysis of heavy metals in sediment could be performed to analyse the anthropogenic impacts on heavy metal pollution along with a risk assessment. An analysis from upstream to downstream sediments is necessary because downstream regions show much more stable pollutant levels compared to upstream and also water column [7].

Metal concentrations in sediments may not increase with decreasing sediment particle as high concentrations of metals have also been found in larger size fractions of sediment [8]. These exceptions probably demonstrate that metal concentrations in sediment are not controlled exclusively by particle size. There are several other factors such as quality and quantity of organic matter, distribution of different mineral phases and metal loading that may also control metal speciation, distribution, accumulation and bioavailability in coastal sediments [9]. Most contaminants, notably metallic compounds, were found to be accumulated in the sediment through complex physical and chemical adsorption mechanisms [10].

Sungai Perak is the 'River of Life' for the Perak State in Malaysia. It flows over $400 \mathrm{~km}$ from a $15,000 \mathrm{~km}^{2}$ catchment that covers $70 \%$ of the state lands and divides the state into two nearly equal halves, and thus forms its natural backbone. This river of life is special in many ways [11]. However, since gaining independence in 1957 and, more recently, driven by Vision 2020, Malaysia is expanding its manufacturing and construction activities which are the main stimuli for the economic growth of the country [12]. Heavy metals produced by various activities around the Perak river, such as chemical manufacturing, municipal effluents and other anthropogenic activities, have contributed to deterioration in the water quality of this water source [13]. Recently, some newspapers reported that there are some problems regarding the Perak River, and news reports also showed that the Perak River is experiencing these problems (Supplementary Materials: Appendix A). Considering the socioeconomic significance of the Perak River as well as the process of sediment acting as a scavenger agent for heavy metals, it is vital to study the distribution and contamination of heavy metals in the surface sediment of the Perak River to understand the natural baseline levels to achieve and monitor the changes that may be affected by anthropogenic activities in the near future.

The present study aimed to find the correlations of heavy metal content in sediment with physicochemical properties such as $\mathrm{pH}$, sediment organic matter content (SOM) and anthropogenic activities, along with geostatistical distribution from upstream to downstream. More specifically, the objectives of this research work were to apply a wide range of extensively used and accurate environmental quality indices like enrichment factors (EF), geoaccumulation index (Igeo), pollution load index (PLI), sediment quality guidelines (SQG), environment toxicity quotient (ETQ) and multivariate statistical analysis to assess the associated ecological risks of the heavy metals and as well as to determine the sediment quality. The present study will help to establish the position of heavy metals present in sediment and their contamination and distribution along the Perak River. Future environmental planning strategies of the Perak River can be made through the understanding the distribution of heavy metals, and the present study can play a significant role in providing this baseline information.

\section{Materials and Methods}

\subsection{Description of the Study Area}

Among the 14 states of Malaysia, Perak has the second largest land area $\left(21,006 \mathrm{~km}^{2}\right)$ and is surrounded by Kedah and Thai state (to the north), the Strait of Malacca (to the west), Kelantan and Pahang (to the east) and Selangor (to the south). Perak has a tropical rainforest climate and there is no dry season. The temperature fluctuates on average from $32{ }^{\circ} \mathrm{C}$ to $34{ }^{\circ} \mathrm{C}$ during the summer, while 
it ranges from $22{ }^{\circ} \mathrm{C}$ to $24{ }^{\circ} \mathrm{C}$ during the winter [11]. The Perak River is one of the largest raw water sources for the whole state of Perak.

\subsection{Sample Collection and Preservation}

A total of 45 surface sediments sampled were collected from 15 different sample locations starting from upstream (S1-S7) to downstream (S8-S15) of the Perak River were collected in the year of 2015. Fifteen different stations were selected to show the distribution and contamination of heavy metals in surface sediments of the Perak River. The details of the sampling stations on the Perak River are shown in Figure 1. Samples of approximately $200 \mathrm{~g}$ of river bed sediment were taken at depths of 0 to $5 \mathrm{~cm}$ using a scoop. Each sediment sample was obtained by randomly collecting three times at each sampling point. The samples were stored in clean polyethylene bags and kept at $4{ }^{\circ} \mathrm{C}$ prior to analysis. Sediment samples were freeze-dried to obtain constant weights, homogenised by grinding in an agate mortar, sieved through a 106- $\mu \mathrm{m}$ aperture nylon sieve, and stored in labelled glass bottles until chemical analyses were carried out [14].

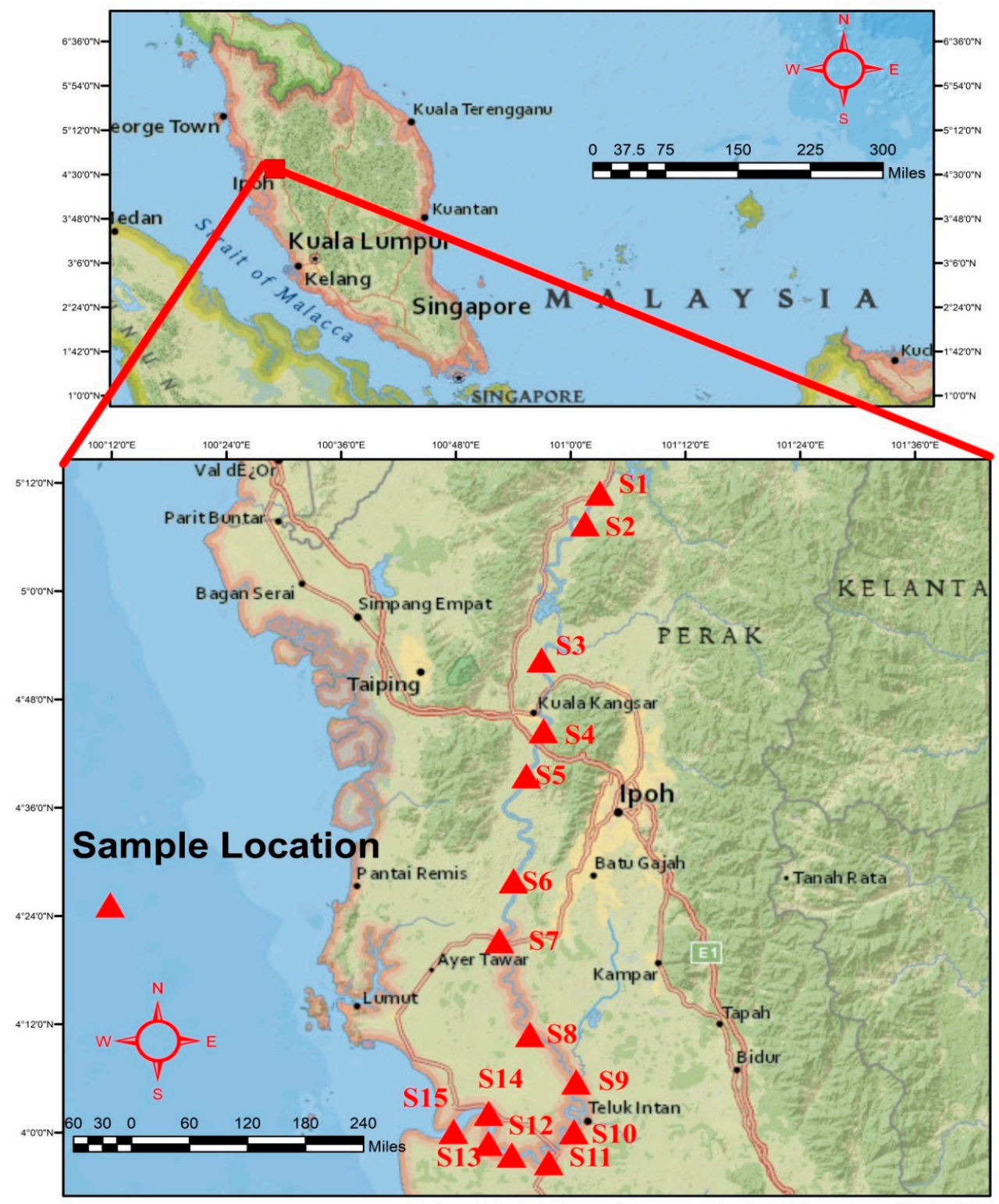

Figure 1. Geographic location of the study area along with the sampling sites in Perak River, Malaysia. 


\subsection{Analysis of Sediment Physicochemical Parameters}

The $\mathrm{pH}$ of the sediments samples were measured in a sediment-to-water ratio of 1:5 by means of a pH meter [14]. To determine the organic matter content of the sediment samples, the loss on ignition method was used with Equations (1) and (2) [15,16].

$$
\operatorname{LOI}(\%)=\frac{\Delta \mathrm{m}}{m s} \times 100
$$

where,

$$
\Delta \mathrm{m}=\left(\mathrm{m}_{\mathrm{s}}+\mathrm{m}_{\mathrm{t}}\right)-\left(\mathrm{m}_{\mathrm{c}}+\mathrm{m}_{\mathrm{t}}\right)=\mathrm{m}_{\mathrm{s}}-\mathrm{m}_{\mathrm{c}}
$$

where, $\Delta \mathrm{m}$ is the loss of mass of the sediment after ignition at $550{ }^{\circ} \mathrm{C}(\mathrm{g}), \mathrm{m}_{\mathrm{s}-}$ is the mass of the

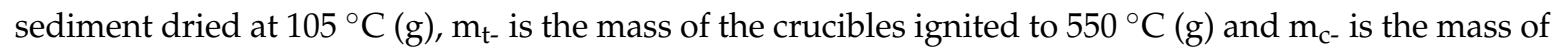
the sediment ignited to $550^{\circ} \mathrm{C}(\mathrm{g})$. The total concentrations of metals in the sediments were determined by means of ICP-OES [17].

Quality assurance (QA) and quality control $(\mathrm{QC})$ made certain that reliable data were produced consistently with minimum error for carrying out the research study. For each set of experiments blanks, certified reference materials (CRMs) and samples were run and corrections applied where necessary. All of the experiments were carried out in three replicates to eliminate any batch-specific errors and only average values were reported [18]. All laboratory equipment used was washed with phosphate-free soap, double-rinsed with distilled water and left in $10 \% \mathrm{HNO}_{3}$ for $24 \mathrm{~h}$ to prevent contamination. Calibration, use of blanks, use of spike samples, performance characteristics of the procedure and reporting of outcome were the significant aspects of QA and QC in the study. The recovery of the total digestion procedure i.e., the reliability of the procedure was at a range of 93 to $110 \%$, indicating the reliability of digesting procedure. (Results are shown in Appendix B).

\subsection{Assessment of Heavy Metals Pollution in Sediments}

\subsubsection{Enrichment Factor (EF)}

The enrichment factor (EF) is a powerful tool used to elucidate the degree of pollution in sediment with respect to a background value [19]. Several authors have successfully used iron ( $\mathrm{Fe}$ ) to normalise heavy metal contaminants [20]. EF was calculated using the Equation (3).

$$
\mathrm{EF}=\frac{\left(\frac{C_{M}}{C_{F e}}\right)_{\text {Sample }}}{\left(\frac{C_{M}}{C_{F e}}\right)_{\text {Background }}}
$$

where, $\left(C_{M} / C_{F e}\right)_{s a m p l e}$ is the ratio of metal and Fe concentration of the sample and $\left(C_{M} / C_{F e}\right)_{b a c k g r o u n d}$ is the geochemical background value of metal to Fe.

\subsubsection{Geoaccumulation Index (Igeo)}

The $\mathrm{I}_{g e o}$ index allows the evaluation of contamination by correlating the obtained current concentration of metals with their pre-industrial concentrations. $\mathrm{I}_{g e o}$ index for the metals was determined using Equation (4) [21]:

$$
\text { Igeo }=\log 2\left(\frac{C n}{1.5 B n}\right)
$$

where, $C_{n}$ is the concentration of metals in soil samples and $B_{n}$ is the geochemical background concentration of the metal $(\mathrm{mg} / \mathrm{kg}$ ) of 0.3 for $\mathrm{Cd}, 45.0$ for $\mathrm{Cu}, 46,700.0(4.67 \%)$ for $\mathrm{Fe}, 20.0$ for $\mathrm{Pb}$ and 95.0 for $\mathrm{Zn}$ [22]. The factor (1.5) is the background matrix correction factor due to lithological variations. 


\subsubsection{Pollution Load Index (PLI)}

The PLI is an empirical index that provides a simple and comparative way to evaluate levels of heavy metal pollution [23]. The CF ratio was estimated by dividing the concentration of each metal in the soil by the background value [20] PLI was calculated using Equation (5).

$$
\mathrm{PLI}={ }^{\mathrm{n}} \sqrt{ }\left(\mathrm{CF}_{1} \times \mathrm{CF}_{2} \times \mathrm{CF}_{3} \times \ldots \ldots \times \mathrm{CF}_{\mathrm{n}}\right)
$$

where, $\mathrm{M}_{\text {etal }}=$ metal concentration obtained from sample, $\mathrm{B}_{\text {ackground value }}=$ geochemical background/baseline value of the metal and $n=$ number of metals.

\subsubsection{Sediment Quality Guidelines (SQG)}

Sediment quality guidelines (SQG) represent the concentration limits of contaminants in sediments [24,25]. The Australian and New Zealand Environment Conservation Council (ANZECC) [26] applies the terminology of sediment quality guideline values (SQGVs) based on the biological effect of contaminants on inhabitants, which was achieved by statistical data evaluation of concentrations and toxicity [27]. Two SQGVs mentioned in the ANZECC guidelines are

$$
\text { Effective range median mean quotient ERMQ }=\frac{\sum_{i=1}^{n} M_{i} / E R M_{i}}{n}
$$

where $M i$ is the concentration of element $i$ in sediment and $E R M_{i}$ is the lower SQGV for element $i$, and

$$
\text { Probable effect level mean quotient PELQ }=\frac{\sum_{i=1}^{n} M_{i} / P E L_{i}}{n}
$$

where $M i$ is the concentration of element $i$ in sediment and $P E L_{i}$ is the upper SQGV for element $i$. The ERMQ values of $<0.1,0.11$ to $0.5,0.51$ to 1.5 and $>1.5$ are related to $12,30,46$ and $74 \%$ toxicity in amphipod survival bioassays, respectively [28]. Similarly, PELQ values of $<0.1,0.11$ to $1.5,1.51$ to 2.3 and $>2.3$ are in accordance with 10,25, 50 and 76\% toxicity, respectively [29]. ANZECC guidelines were followed for determining the ERMQ and PELQ of all the collected sediment samples.

\subsubsection{Sediment Environmental Toxicity Quotient (ETQ)}

The environmental toxicity quotient (ETQ) was determined to test the sediment quality based on toxicity [30]. It was determined by multiplying the concentration of each contaminant measured in the sediment samples with the corresponding hazard intensity. The hazard intensity of each parameter was determined according to the Priority List of Hazardous Substances prepared by the US Agency for Toxic Substances and Disease Registry (ATSDR) [31]. ETQ was determined by Equation (8).

$$
\text { Environmental Toxicity Quotient }(\mathrm{ETQ})=\frac{\sum_{i=1}^{n} T S_{i} \times C_{i} / T S_{A s}}{n}
$$

where $C_{i}$ is the measured concentration of the element $\mathrm{i}$ and $\mathrm{n}$ is the number of the analysed elements. $T S_{i}$ is the total score for each element $\left(T_{A s}=1674, T_{P b}=1531, T_{Z n}=915, T_{C d}=1320\right.$, and $\left.T_{C u}=807\right)$ and $\mathrm{TS}_{\mathrm{As}}$ is the total score of arsenic, which has the highest TS published by the Agency for Toxic Substances and Disease Registry (ATSDR). Pollution ranges (toxicity level) were assigned based on the ETQ values, $<10$ low toxicity, $10-50$ moderate toxicity, 50-100 high toxicity, 100-300 very high toxicity and $>300$ extremely high toxicity [31]. 


\subsection{Analytical Methods}

\subsubsection{Statistical Method}

All statistical analyses were computed by using SPSS version 20. Analysis of variances (ANOVA) was applied to compare the concentrations of five selected heavy metals in sample collected from 15 different stations in the Perak River and the metal-metal correlation values. The graphs were created with Origin (2017) for Windows. Factor analysis based on principal component analysis (PCA) was used to ascertain sources of contamination. Cluster analysis (CA) was applied to identify different geochemical groups, which enabled clustering of the samples with similar metal contents. CA was formulated according to the single linkage technique, and the linkage distance [(Dlink/Dmax $) \times 100$ ] was used for measuring the distance between clusters of similar metal contents [32].

\subsubsection{Geostatistical Methods}

The inverse distance weighted (IDW) method was applied to show the spatial distribution of heavy metals in the surface sediment. The IDW interpolation calculated the cell values for the unmeasured site by averaging the sampled data in the target site. More weight is observed when the measured point is close to the centre of the prediction cell. ArcGIS 10.2.2 was used for analysis. The power of two and the number of 30 neighbouring samples were chosen to show both spatial variation and patterns of the heavy metals. Considering the large area of the Perak River, along with its zigzag shape, we have made the distribution an upstream and downstream basis. We created a polygon very similar to Perak River and used this polygon for interpolation. Total root mean square (RMS) error was maintained below $1(0.001-0.002)$ to ensure the proper interpolation of data.

\section{Results and Discussions}

\subsection{Physicochemical Parameter of Sediments}

The results of the analysed parameters such as $\mathrm{pH}$ and SOM are given in Table 1 . The $\mathrm{pH}$ level at sites $\mathrm{S} 4$ to $\mathrm{S} 12$ and $\mathrm{S} 14$ revealed a low value (pH: 5.56-6.92), i.e., the surface sediments of these stations were in acidic conditions, while sites S13 and S15 revealed alkaline conditions (pH: 7.22-7.33).

Table 1. Heavy metal concentrations $(\mu \mathrm{g} / \mathrm{g})$ in the surface sediments of Perak River $(n=3)$.

\begin{tabular}{lccccccc}
\hline Station & $\mathbf{p H}$ & $\mathbf{S O M}(\mathbf{\%})$ & $\mathbf{P b}$ & $\mathbf{Z n}$ & $\mathbf{C d}$ & $\mathbf{C u}$ & $\mathbf{F e}(\%)$ \\
\hline S1 & $7.05 \pm 0.09$ & 4.4 & $25.4 \pm 6.09$ & $33.39 \pm 12.80$ & $2.77 \pm 0.53$ & $11.68 \pm 2.32$ & $20.88 \pm 1.53$ \\
S2 & $7.05 \pm 0.12$ & 4.4 & $17.19 \pm 3.34$ & $21.31 \pm 2.95$ & $1.51 \pm 0.50$ & $6.82 \pm 6.52$ & $56.58 \pm 9.29$ \\
S3 & $7.43 \pm 0.10$ & 4.4 & $22.79 \pm 5.13$ & $49.70 \pm 10.27$ & $2.07 \pm 0.76$ & $10.98 \pm 1.50$ & $40.12 \pm 28.59$ \\
S4 & $6.92 \pm 0.11$ & 4.8 & $14.56 \pm 4.15$ & $26.53 \pm 4.23$ & $1.94 \pm 0.36$ & $6.60 \pm 2.19$ & $42.94 \pm 42.49$ \\
S5 & $6.02 \pm 0.09$ & 6.2 & $33.13 \pm 12.16$ & $51.78 \pm 18.36$ & $3.62 \pm 1.22$ & $17.26 \pm 6.32$ & $36.40 \pm 9.14$ \\
S6 & $6.13 \pm 0.08$ & 6.6 & $19.14 \pm 3.67$ & $31.99 \pm 6.00$ & $2.21 \pm 0.36$ & $8.21 \pm 0.93$ & $21.76 \pm 44.56$ \\
S7 & $5.56 \pm 0.03$ & 7.2 & $35.06 \pm 21.09$ & $58.34 \pm 31.80$ & $2.77 \pm 0.11$ & $16.44 \pm 8.74$ & $38.78 \pm 17.65$ \\
S8 & $6.59 \pm 0.44$ & 8.2 & $30.57 \pm 2.97$ & $50.03 \pm 7.36$ & $3.36 \pm 0.71$ & $12.51 \pm 1.80$ & $31.34 \pm 4.88$ \\
S9 & $6.77 \pm 0.24$ & 8.8 & $27.60 \pm 9.42$ & $47.29 \pm 8.45$ & $3.63 \pm 0.26$ & $13.78 \pm 3.16$ & $36.80 \pm 2.05$ \\
S10 & $6.74 \pm 0.24$ & 9.4 & $17.75 \pm 3.10$ & $37.37 \pm 1.03$ & $2.16 \pm 0.47$ & $8.55 \pm 0.80$ & $20.24 \pm 1.38$ \\
S11 & $6.91 \pm 0.17$ & 9.4 & $31.96 \pm 9.44$ & $49.03 \pm 14.28$ & $3.83 \pm 0.61$ & $9.82 \pm 2.97$ & $37.51 \pm 7.52$ \\
S12 & $6.53 \pm 0.07$ & 11 & $44.80 \pm 25.70$ & $95.53 \pm 63.24$ & $3.68 \pm 0.62$ & $183.52 \pm 25.85$ & $40.55 \pm 6.82$ \\
S13 & $7.22 \pm 0.07$ & 12 & $60.77 \pm 6.65$ & $160.48 \pm 16.98$ & $4.02 \pm 0.10$ & $50.83 \pm 8.33$ & $39.22 \pm 4.00$ \\
S14 & $6.36 \pm 0.27$ & 12.6 & $29.69 \pm 6.33$ & $77.92 \pm 5.54$ & $3.93 \pm 0.54$ & $18.13 \pm 2.08$ & $39.30 \pm 3.85$ \\
S15 & $7.33 \pm 0.08$ & 13 & $22.31 \pm 10.78$ & $51.27 \pm 17.01$ & $2.62 \pm 0.36$ & $19.14 \pm 16.30$ & $23.60 \pm 1.09$ \\
Range & $5.56-7.43$ & $4.4-13.00$ & $25.40-60.77$ & $21.31-160.48$ & $1.51-4.02$ & $6.60-183.52$ & $20.24-56.58$ \\
\hline
\end{tabular}

The alkaline conditions noted at certain sampling stations (particularly in downstream region) might be explained by the intense influence of the calcareous materials deposition in the downstream region. Again, seawater intrusion by tidal pumping or sea level rising might also be responsible for alkaline condition of sediment of the Perak River (Figure 1). This study revealed S1 had the lowest average SOM percentage (4.40\%), while S13 had the highest percentage of SOM (13\%), indicating that 
the downstream area is rich with SOM content. The studied metal concentrations in the sediment were in the order of $\mathrm{Fe}>\mathrm{Zn}>\mathrm{Pb}>\mathrm{Cu}>\mathrm{Cd}$. The $\mathrm{Zn}$ concentrations ranged between 21.31 and $160.48 \mu \mathrm{g} / \mathrm{g}$ with an overall average of $55.38 \mu \mathrm{g} / \mathrm{g}$. The highest average concentrations of $\mathrm{Zn}$ was found at S13 $(160.48 \pm 16.98 \mu \mathrm{g} / \mathrm{g})$ and the lowest was found at S2 $(21.31 \pm 2.95 \mu \mathrm{g} / \mathrm{g})$. Again, the highest percentage of $\mathrm{Zn}$ distribution was reported at $\mathrm{S} 13$ at $~ 51 \%$, which revealed that half of the heavy metals pollution at $\mathrm{S} 13$ came from $\mathrm{Zn}$. Fe concentrations were as low as $20.24 \%$ at $\mathrm{S} 10$ and as high as $56.58 \%$ at $\mathrm{S} 2$ with overall average concentration of $35.05 \%$.

The average value of $\mathrm{Pb}$ concentrations was $28.86 \mu \mathrm{g} / \mathrm{g}$ and the highest concentration $\mathrm{Pb}$ was at $\mathrm{S} 13(60.77 \pm 6.65 \mu \mathrm{g} / \mathrm{g})$, while the lowest was at $\mathrm{S} 4(14.56 \pm 4.15 \mu \mathrm{g} / \mathrm{g})$. In the case of $\mathrm{Cu}$, the most noteworthy concentration was accounted for at $\mathrm{S} 12(183.52 \pm 44.80 \mu \mathrm{g} / \mathrm{g})$ and the least was at $\mathrm{S} 4(6.60 \pm 2.19 \mu \mathrm{g} / \mathrm{g})$. Finally, Cd concentrations ranged from 1.51 to $4.02 \mu \mathrm{g} / \mathrm{g}$ with an overall average value of $2.94 \mu \mathrm{g} / \mathrm{g}$. At some specific sampling areas, high pollution levels of metals were observed which might be because of the local concentration of civil waste, transportation activities, farming exercises and natural weathering. For example the highest concentrations of $\mathrm{Cd}$ at S13 $(4.02 \pm 0.10 \mu \mathrm{g} / \mathrm{g})$ were observed because various metal processing industries, numerous agriculture land and living residents were existed in and around of the Perak River. Again, various shipping construction industries and floating restaurants had contributed to high concentrations of $\mathrm{Pb}$ at $\mathrm{S} 13(60.77 \mu \mathrm{g} / \mathrm{g})$. The spatial distribution of heavy metals for all stations was compared between upstream and downstream areas of the Perak River by means of a prediction map (Figure 2). The prediction map clearly defines the distribution of heavy metals, where the red colour indicates the highest concentrations and the green colour signifies the lowest concentrations in both upstream and downstream areas. From the maps, it is very clear that the concentrations of $\mathrm{Pb}, \mathrm{Zn}, \mathrm{Cd}$ and $\mathrm{Cu}$ were higher in downstream areas than upstream, but Fe showed a different distribution. The distribution of $\mathrm{Zn}$ and $\mathrm{Pb}$ for both upstream and downstream areas was similar and, as stated earlier, $\mathrm{Zn}$ was reported with the highest concentration at $\mathrm{S} 13 ; \mathrm{Pb}$ also followed the same trend at this station. This indicates that $\mathrm{S} 13$ had many intense activities nearby that contributed $\mathrm{Zn}$ and $\mathrm{Pb}$ to the river. Unlike the pattern of other heavy metals such as $\mathrm{Pb}, \mathrm{Zn}, \mathrm{Cd}$ and $\mathrm{Cu}$, the upstream areas of the river showed high concentrations of Fe. The downstream map also indicates slightly higher concentration (although 1.5 times less than those upstream) of Fe especially at stations 12 and 13, because of the high domestic effluent from the dominant sources of residential areas and construction activities (Appendix C). From the heavy metal distribution pattern in the surface sediment, it is very evident that for most metals the high concentration values were gathered in the downstream region. This may be due to the higher SOM content in downstream areas along with the slower flow rate of the river water near to the Andaman Sea. 

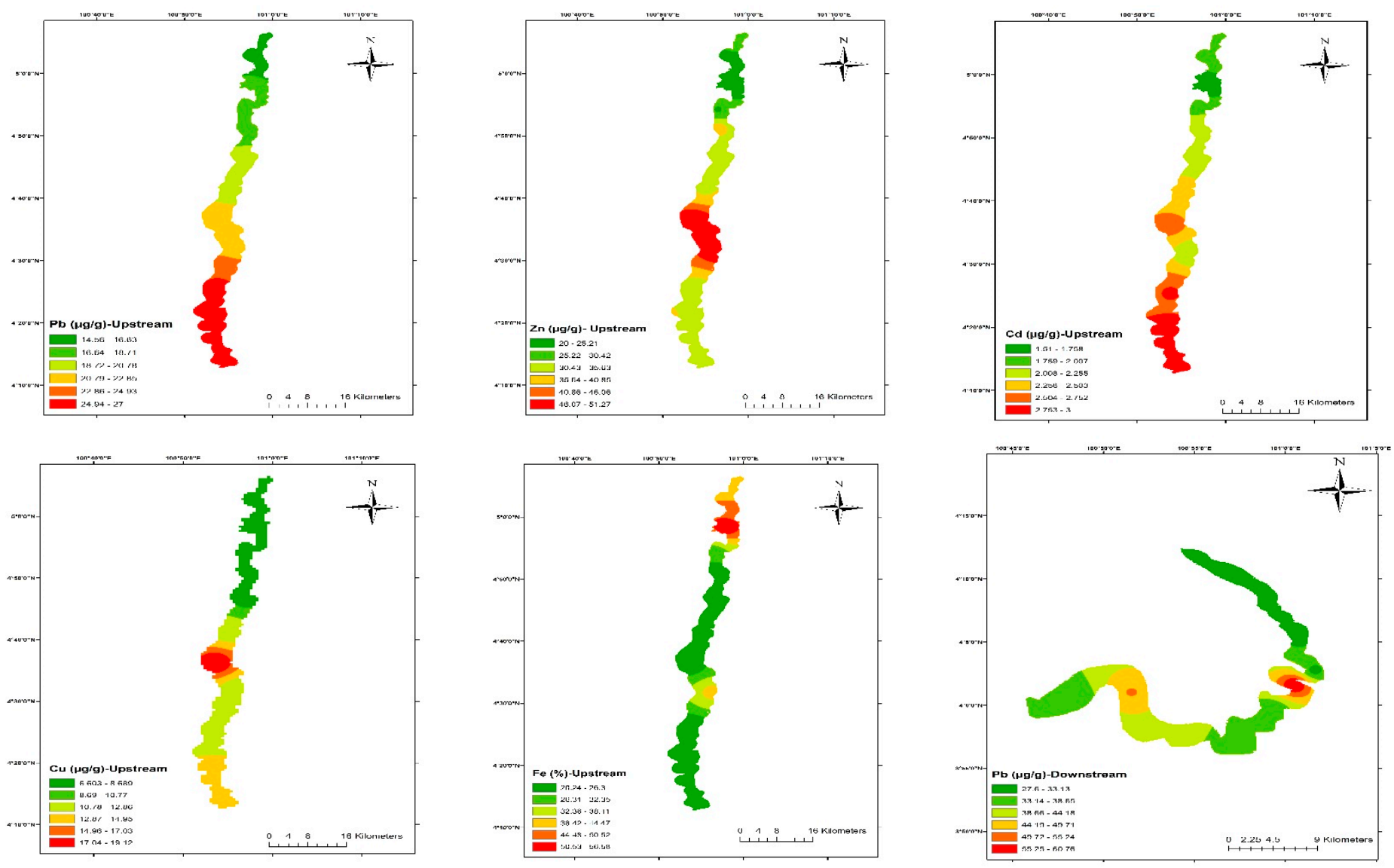

Figure 2. Cont. 

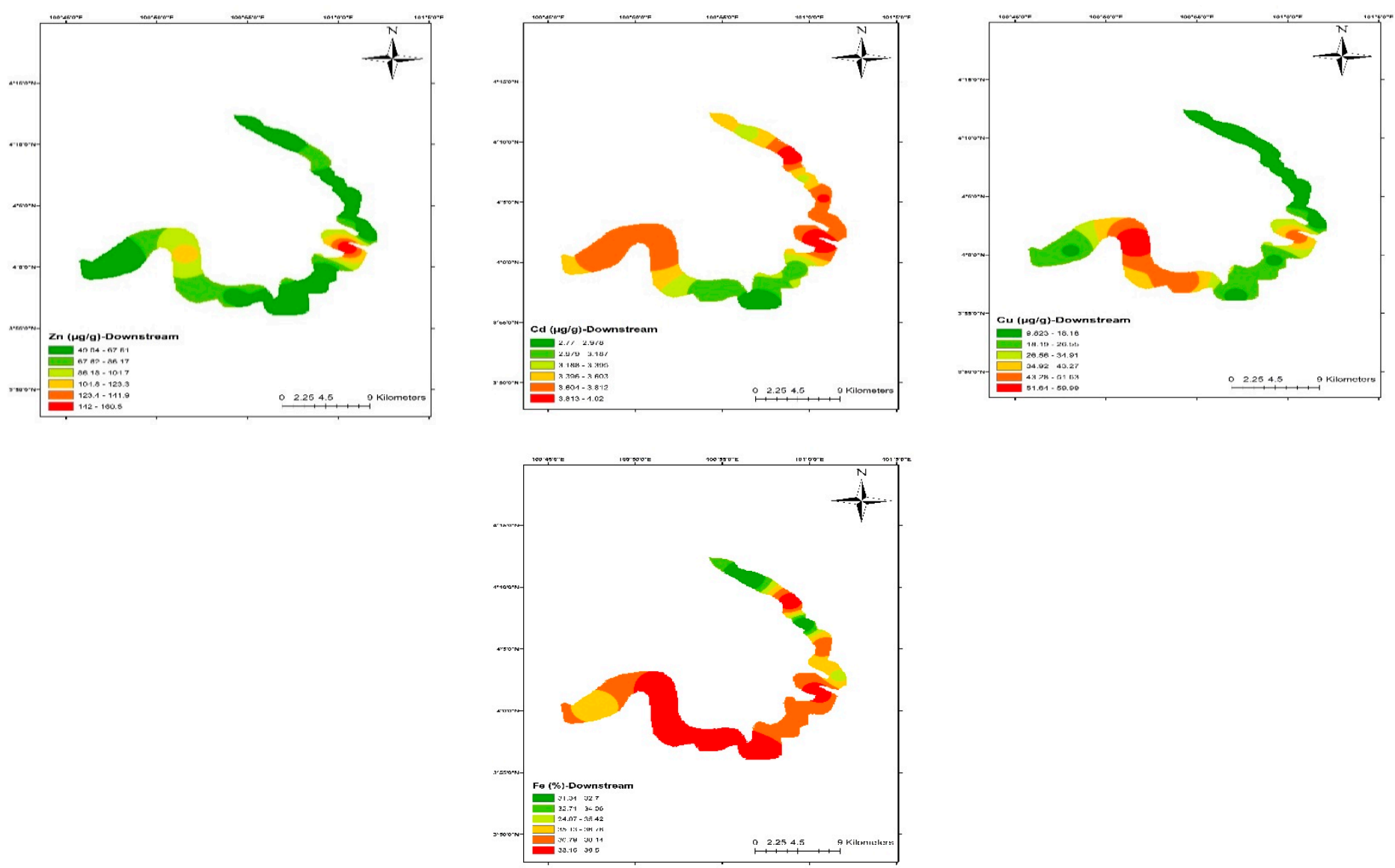

Figure 2. Geostatistical prediction maps of heavy metals in the surface sediment in upstream and downstream areas of the Perak River. 
Figure 3 depicts the correlation of $\mathrm{pH}$ with the heavy metal content of the sediment. Both $\mathrm{Zn}$ and Fe showed a negligible positive correlation, while $\mathrm{Cd}, \mathrm{Cu}$ and $\mathrm{Pb}$ showed a negative correlation with $\mathrm{pH}$ values, similar to the results obtained by Idriss et al. [33]. High $\mathrm{pH}$ values promote adsorption and precipitation of metal ions in sediment through complex formation, while low $\mathrm{pH}$ values can weaken the strength of metal association and impede their retention in sediments, resulting in its release to water [34]. For example, the higher concentration of heavy metals at S13 is due to the higher $\mathrm{pH}$ of sediment. This is because a decrease in $\mathrm{pH}$ will increase the activity of some ions $\mathrm{H}^{+}, \mathrm{Fe}^{3+}$, $\mathrm{Al}^{3+}$ and hydroxide) and the cations will compete with heavy metals for negative sorption sites in the sediments [35]. Thus, there is a negative correlation of $\mathrm{Cd}, \mathrm{Cu}$ and $\mathrm{Pb}$, with $\mathrm{pH}$ indicating that the $\mathrm{pH}$ may potentially be the one of the main factor affecting the distribution of these metals in the surface sediment of the Perak River.

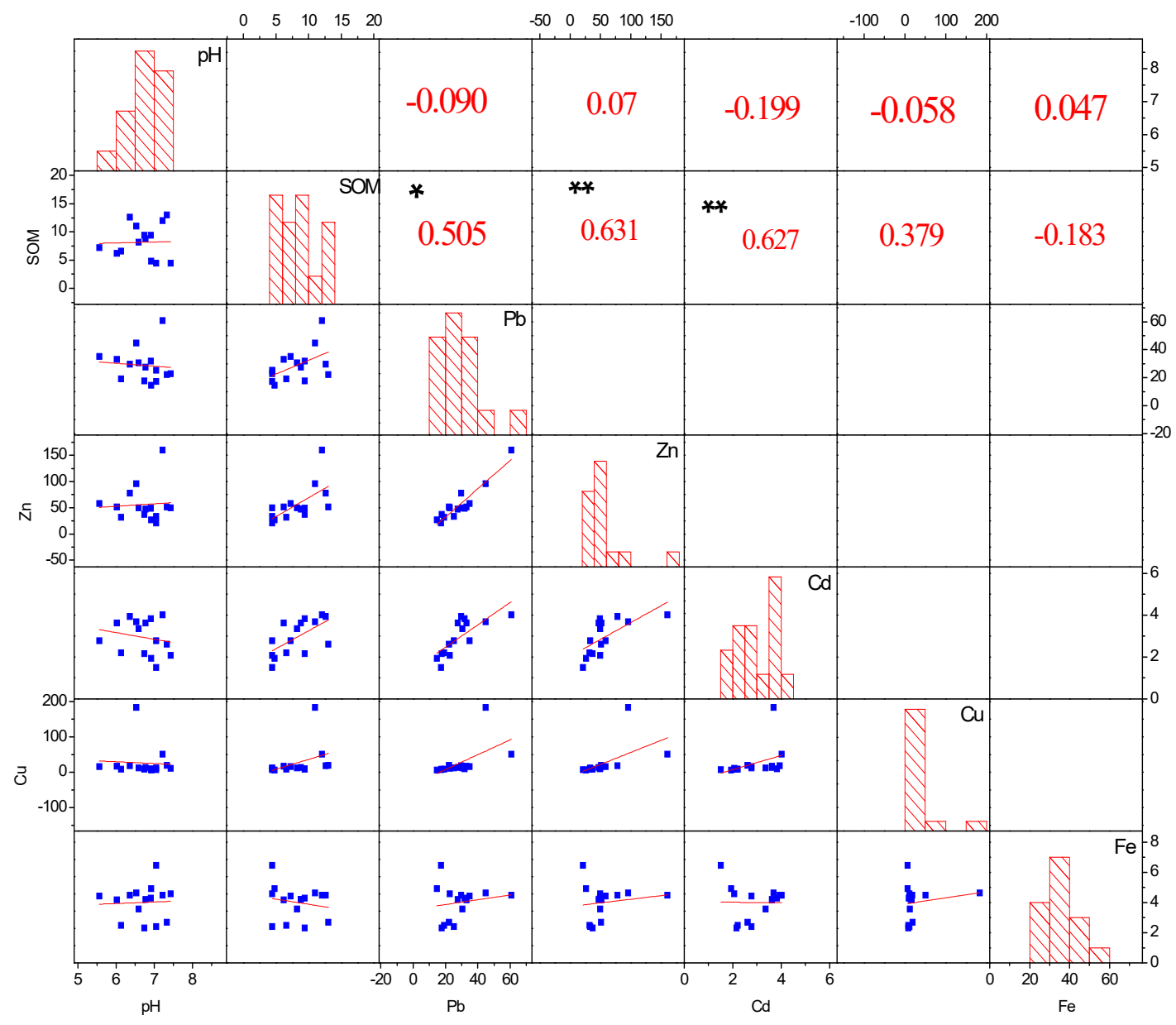

Figure 3. Correlation of heavy metal concentration with $\mathrm{pH}$ and sediment organic matter content $(\mathrm{SOM}){ }^{* *}$ Correlation is significant at the 0.01 level (2-tailed) * Correlation is significant at the 0.05 level (2-tailed).

$\mathrm{Pb}, \mathrm{Zn}$ and $\mathrm{Cd}$ were strongly correlated $(p<0.01$ for $\mathrm{Zn}$ and $\mathrm{Cd}$, and $p<0.05$ for $\mathrm{Pb}$ ) with the organic matter content in sediment, while $\mathrm{Cu}$ was moderately correlated with $\mathrm{SOM}$, indicating that the distribution of $\mathrm{Pb}, \mathrm{Zn}$ and $\mathrm{Cd}$ was strongly controlled by the organic matter content in this area. Significant correlation of $\mathrm{Pb}, \mathrm{Zn}$ and $\mathrm{Cd}$ with organic matter may be due to the high stability constants of the forming organic heavy metal $(\mathrm{Pb}, \mathrm{Zn}$ and $\mathrm{Cd})$ compounds. Again organic compounds usually play an important role in heavy metal transformation in rivers because of its high sorption properties. The complexation reaction between heavy metals and organic complexants is usually recognised as the most important reaction pathway, and the mobility of trace metals in natural water environment 
can be influenced by this reaction [36]. The insignificant correlation of copper with sediment organic matter indicates that it might be less bioavailable in the sediments due to its remobilising tendency in oxidising state. Whereas the negative correlation between SOM and Fe might be due to the highest amount of organic matter content being in the downstream sediment as well as the lower stability constants of organic-iron compounds complexes. This could be because organic matter present in domestic sewage acts as a reducing agent which converts iron mineral into its soluble form $\left(\mathrm{Fe}^{3+}\right.$ to $\left.\mathrm{Fe}^{2+}\right)$, resulting in its abundance in river water rather than in the sediment [37].

\subsection{Risk Assessment}

The EF is used to estimate the heavy metal sources and the degree of anthropogenic influence based on the use of a normalisation element [38]. The calculated EF results were compared with the assessment criteria as suggested by Birth (2003) and Chen et al. (2007) [39,40]. The EF values for the studied metals were in the order of $\mathrm{Cd}>\mathrm{Pb}>\mathrm{Zn}>\mathrm{Cu}$ (Figure 4). In general, the average EF values for all metals were $<1.0$, suggesting no anthropogenic impact on metal levels in the river sediment.

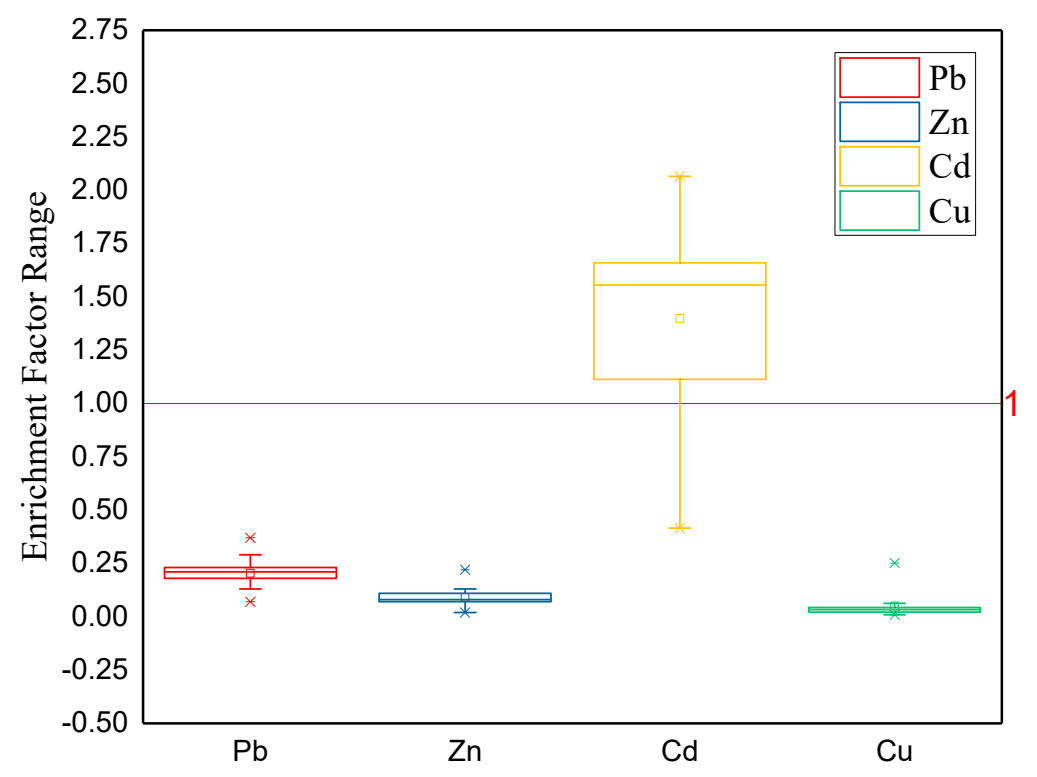

Figure 4. Enrichment factor of surface sediment in the Perak River (straight line at point 1 represents EF index reference line [39,40]; EF < 1, no enrichment; EF 1.0-3.0, minor enrichment; EF 3.0-5.0, moderate enrichment).

The EF values for $\mathrm{Cd}$ ranged from 0.415 to 2.07 , indicating that $20 \%$ of the stations were categorised as having no enrichment and $80 \%$ as having minor enrichment. The EF values for $\mathrm{Pb}$ ranged from 0.07 to $0.37, \mathrm{Zn}$ ranged from 0.02 to 0.22 and $\mathrm{Cu}$ ranged from 0.009 to 0.251 , suggesting that $100 \%$ of these stations can be categorised as no enrichment for these metals. The EF values of $\mathrm{Pb}, \mathrm{Zn}$ and $\mathrm{Cu}$ were less than 1.5, suggesting that natural sources have a major contribution to their availability, whereas the EF values of $\mathrm{Cd}$ were all close to 1.5, indicating an anthropogenic input for $\mathrm{Cd}$ concentration.

The pollution intensity based on the calculated Igeo results was in the order of $\mathrm{Cd}>\mathrm{Fe}>\mathrm{Pb}>$ $\mathrm{Zn}>\mathrm{Cu}$ (Figure 5). Based on Muller's scale, the average Igeo values for all detected metals indicated that only two metals have Igeo $>0$. For Cd, approximately $53 \%$ of the sampling stations were 'moderately-to-heavily contaminated' (Igeo $=2.11$ to 3.16 ), $40 \%$ were 'heavily contaminated', while the remaining stations were 'moderately contaminated'. 


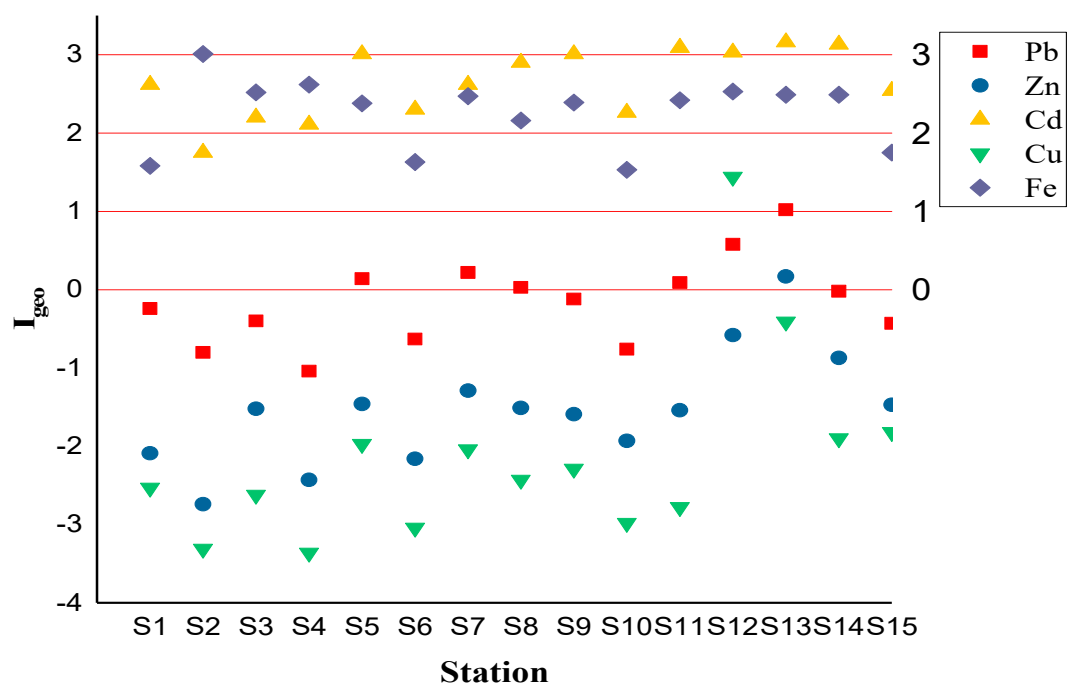

Figure 5. Igeoaccumulation index surface sediment in the Perak River (the reference line at point 0,12,3 represents the different Muller classes). $I_{\text {geo }}<0$, uncontaminated; $0<I_{\text {geo }}<1$, uncontaminated-to-moderately uncontaminated; $0<\mathrm{I}_{\text {geo }}<2$, moderately contaminated; $2<$ $\mathrm{I}_{\text {geo }}<3$, moderately-to-heavily contaminated; $3<\mathrm{I}_{\text {geo }}<4$, heavily contaminated; $4<\mathrm{I}_{\text {geo }}<5$, heavily-to-extremely contaminated; $I_{\text {geo }}>5$, extremely contaminated.

For $\mathrm{Fe}$, approximately $67 \%$ of the sampling stations were 'moderately-to-heavily contaminated' (Igeo $=2.16$ to 3.0 ), 27\% were 'uncontaminated-to-moderately contaminated', while the remaining stations were 'heavily contaminated'. For $\mathrm{Pb}$, approximately $60 \%$ of the sampling stations were 'uncontaminated' (Igeo $=-1.04$ to -0.02 ), 33\% were 'uncontaminated-to-moderately contaminated', while the remaining stations were 'moderately contaminated'.

The values of PLI (Figure 6) were found to be generally high $(>1)$ in all the studied stations, indicating that $100 \%$ of the sites had metal contamination to some extent. Among them, the contamination factor (Appendix D) of both $\mathrm{Cd}$ and Fe went beyond the maximum limit (CF $>6$-very high concentration), which specified that these two metal were responsible for major pollution in the Perak river [41]. This confirmed that the Perak River is facing probable environmental pollution especially with dangerous heavy metals ( $\mathrm{Cd}$ and $\mathrm{Fe}$ ) resulting from an increased rate of non-treated industrial waste discharged to the Perak River.

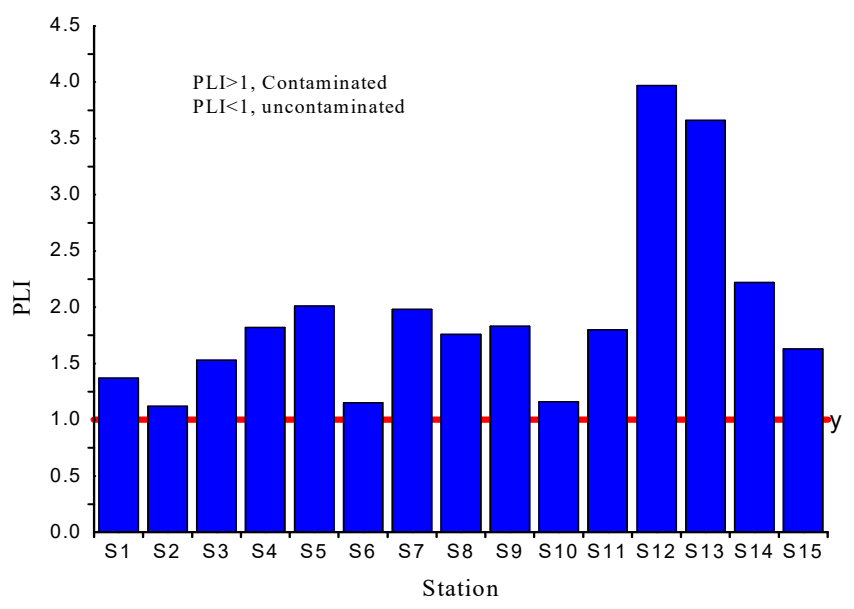

Figure 6. Pollution load index of surface sediment in the Perak River. Straight line at point 1 represents the reference line for pollution indication [42]. 
The estimated ERMQ values suggest that the sediments from both upstream and downstream sites had an average toxicity of $30 \%$, a similar level of toxicity (25\%) was also indicated by the PELQ value (Table 2). The ETQ values confirmed that the sediments of the Perak River are moderately toxic to the inhabitants and that this toxicity level is higher in downstream region as compared to the upstream regions. According to the ETQ based toxicity level, sediments of site S2 had the lowest toxicity which is also shown by the PLI index (Figure 7).

Table 2. Sediment quality guidelines and environment toxicity quotient.

\begin{tabular}{ccccccccccccccccc}
\hline Stations & S1 & S2 & S3 & S4 & S5 & S6 & S7 & S8 & S9 & S10 & S11 & S12 & S13 & S14 & S15 \\
\hline Stream & \multicolumn{10}{c}{ Upstream } \\
\hline ERMQ & 0.17 & 0.11 & 0.16 & 0.11 & 0.23 & 0.14 & 0.22 & 0.22 & 0.22 & 0.14 & 0.23 & 0.411 & 0.43 & 0.26 & 0.18 \\
PELQ & 0.31 & 0.18 & 0.26 & 0.21 & 0.41 & 0.24 & 0.36 & 0.38 & 0.39 & 0.24 & 0.42 & 0.69 & 0.64 & 0.44 & 0.31 \\
ETQ & 12.32 & 7.96 & 13.73 & 8.13 & 17.44 & 10.17 & 18.51 & 16.0 & 15.15 & 10.62 & 15.95 & 46.14 & 42.74 & 20.40 & 14.93 \\
\hline
\end{tabular}

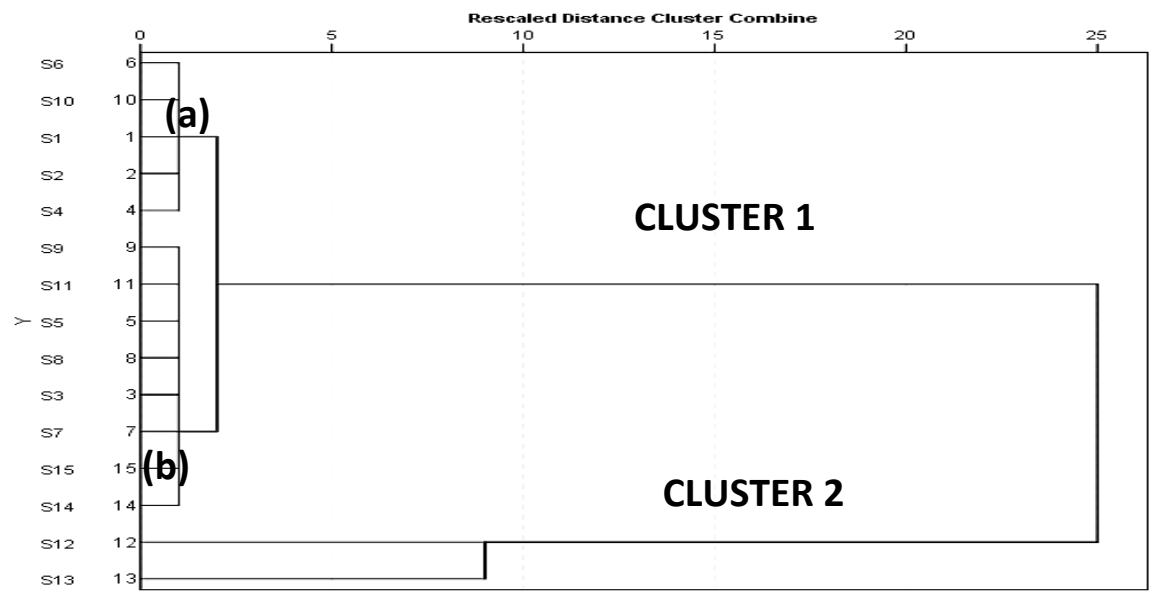

Figure 7. Cluster analysis ("a" and "b" represent sub cluster) of sampling stations in the Perak River.

The differences in the indices results may be due to the differences in sensitivity of these indices towards the sediment pollutants, which means that the basis of the different indices is different [43]. Overall, the heavy metals in the surface sediment of Perak River have a moderate ecological risk. However, on the basis of individual metal contribution $\mathrm{Cd}$ and Fe showed the greatest risk and should be considered as major pollutants of the Perak River.

\subsection{Heavy Metals Sources}

The results of EF, Igeo and CF (Appendix D) indicated that the levels of $\mathrm{Pb}, \mathrm{Zn}$ and $\mathrm{Cu}$ presented a low potential ecological risk, suggesting that this group of elements might originate from natural sources [44]. However, the highest concentration of $\mathrm{Pb}$ at S13 may be contributed to by various factories, such as a shipping factory, a match factory and a timber factory. Similarly, apart from natural sources, the highest value of $\mathrm{Cu}$ at $\mathrm{S} 12$ may be due to the residential area and the fishing port. Additionally, $\mathrm{Cu}$ can be retained by sediment through exchange and specific adsorption mechanisms but precipitation may also be an important mechanism of retention in polluted sediments. It is suggested that agrochemicals especially phosphorite fertilisers and residential waste were the major sources of $\mathrm{Cu}$ [45]. The highest concentration of $\mathrm{Zn}$ at S13 might be due to the influence of prevailing construction and shipping manufacturing activities [13]. The second group of metals (Fe and Cd) had greater concentrations in the sediment than the first group of metals. This indicates that anthropogenic activity was also contributing to the concentrations of $\mathrm{Fe}$ and $\mathrm{Cd}$ in the sediment. Metal processing industries, large areas of agricultural land and residential areas were existed around of the Perak River were likely to be the sources of $\mathrm{Cd}$ in the present sediments. On the other hand, high domestic 
effluent from the sources such as residential areas and construction activities contributed to the high Fe concentrations.

Various multivariate techniques such as CA, PCA and intermetal relationships have been shown to be useful for identifying sources of heavy metals and for interpreting their spatial variations. The CA classified the sampling stations into two major clusters (Figure 7). Cluster 1 consists of two subclusters. Cluster 1(a) includes less impacted stations (S1, S2, S4, S6 and S10) that were located further inland from the estuary and Straits of Malacca. Cluster 1(b) includes stations (S3, S5, S7, S8, S9, S11, S14 and S15) that were close to the estuary and Straits of Malacca. Based on the locations and variable concentrations at these stations, this study concluded that seawater intrusion strongly affected the parts of the study area. These stations were characterised by high $\mathrm{pH}$ values compared to the other stations. Cluster 2 consists of stations S12 and S13, which are mainly located in the downstream part of the study area. According to Malaysian Department of Environment, the population density of those sites was considerably higher and the land use pattern was predominantly urban activities, agricultural fields and the sampling stations were located in close proximity to the major pollution sources, such as industrial discharge, domestic sewage from treatment plants, construction projects and a shipping port [46].

A clear pattern of strong associations was found among the metal pairs in the sediment sample, which were $\mathrm{Pb}-\mathrm{Zn}, \mathrm{Pb}-\mathrm{Cd}, \mathrm{Zn}-\mathrm{Cd}, \mathrm{Pb}-\mathrm{Cu}, \mathrm{Zn}-\mathrm{Cu}$ and $\mathrm{Cd}-\mathrm{Cu}$ (Table 3). Based on the Pearson correlation coefficients, $\mathrm{Zn}$ showed significant strong positive correlation with $\mathrm{Pb}, \mathrm{Cd}$ and $\mathrm{Cu}(r=0.872,0.649$ and 0.591 , respectively; $p<0.05$ ). These strong correlations among metal-to-metal pairs are an indication of common sources of these metals as well as similar geochemical characteristics. There was a weak negative correlation between Fe and $\mathrm{Cu}(r=-0.027)$, Fe and $\mathrm{Zn}(r=-0.027)$ and Fe and $\mathrm{Cd}(r=-0.190)$ suggesting different origin or dissimilar sedimentological properties of iron.

Table 3. Metal-to-metal correlation coefficient matrix for metals in sediment samples.

\begin{tabular}{cccccc}
\hline & $\mathbf{P b}$ & $\mathbf{Z n}$ & $\mathbf{C d}$ & $\mathbf{C u}$ & $\mathbf{F e}$ \\
\hline $\mathrm{Pb}$ & 1 & & & & \\
$\mathrm{Zn}$ & $0.872^{* *}$ & 1 & & & \\
$\mathrm{Cd}$ & $0.649^{* *}$ & $0.615^{* *}$ & 1 & & \\
$\mathrm{Cu}$ & $0.591^{* *}$ & $0.600^{* *}$ & $0.346^{*}$ & 1 & 1 \\
$\mathrm{Fe}$ & -0.027 & -0.027 & -0.190 & 0.047 & \\
$*$ Correlation is significant at the 0.01 level (2-tailed). * Correlation is significant at the 0.05 level (2-tailed).
\end{tabular}

The PCA results of the heavy metals concentrations of the sediment surface sediment samples are shown in Figure 8. The PCA yielded two principal components with eigenvalues $>1$. The first principal component $(\mathrm{PC} 1$ ) explained $59.41 \%$ of the total variation (eigenvalue $=2.97$ ), and was loaded with $\mathrm{Pb}, \mathrm{Zn}, \mathrm{Cd}$ and $\mathrm{Cu}$. PC1 represents moderately strong correlation with four of the variables; it increases with increasing $\mathrm{Cu}(0.40), \mathrm{Cd}(0.47), \mathrm{Pb}(0.56)$ and $\mathrm{Zn}(0.54)$. On the other hand, PC2 explained $20.73 \%$ (eigenvalue $=1.04$ ) of the total variance and was strongly correlated with $\mathrm{Fe}(0.93)$. PCA analysis showed that metal elements assembled in two major groups, where $\mathrm{Pb}, \mathrm{Zn}, \mathrm{Cd}$ and $\mathrm{Cu}$ constituted the first group and have similarities in their sources and distribution. Fe is slightly further away from the first group and has contribution from some other sources as well. 


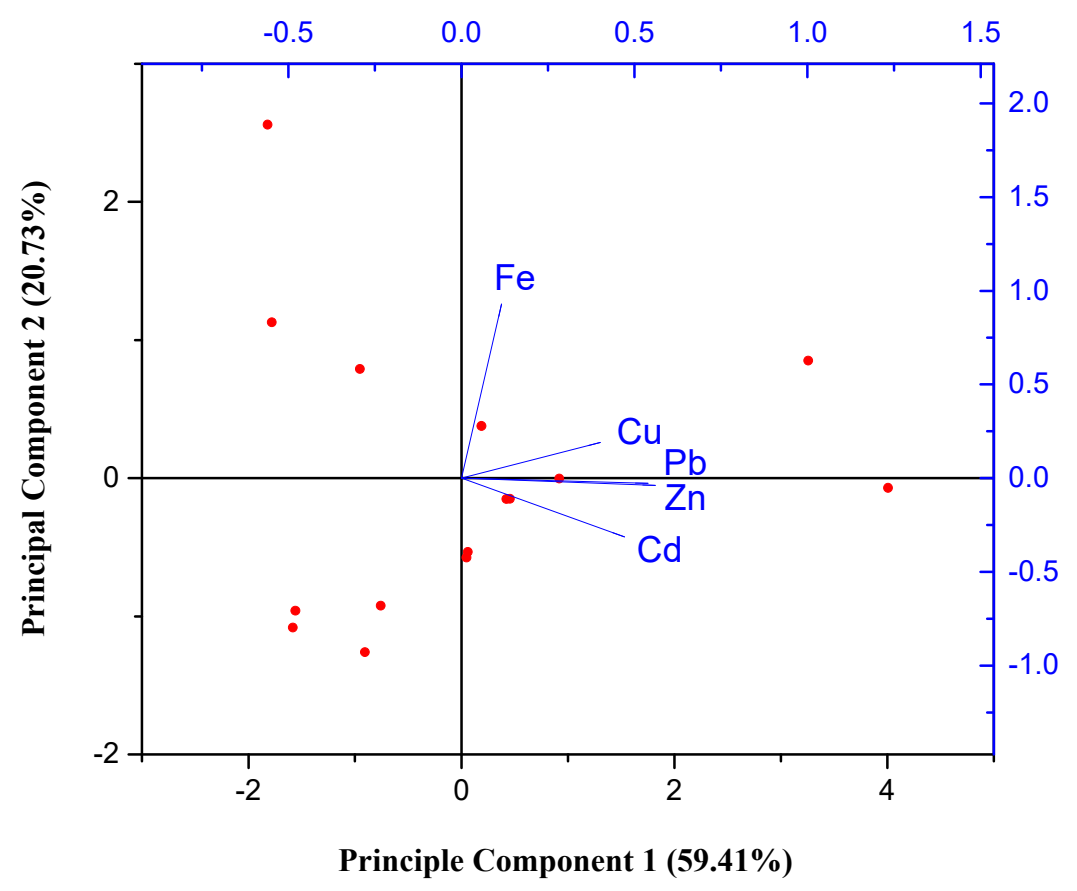

Figure 8. Principal component analysis (PCA) plot showing the loading of two components influencing variation of heavy metals in the sediments.

\subsection{Comparison of Observed Result with Sediment Guidelines and Previous Study}

Comparison of heavy metal level in sediment from this study with various international guidelines and previous studies provides better perspectives of the state of metal toxicity in the sediment (Table 4). This study revealed that the concentrations of $\mathrm{Pb}(28.86 \mu \mathrm{g} / \mathrm{g}), \mathrm{Zn}(55.38 \mu \mathrm{g} / \mathrm{g})$ and $\mathrm{Cu}(24.67 \mu \mathrm{g} / \mathrm{g})$ were below the US EPA guidelines, however Cd $(2.94 \mu \mathrm{g} / \mathrm{g})$ exceeded the guideline's value of 0.99 $\mu \mathrm{g} / \mathrm{g}$ [47]. The comparison of elemental concentrations with the ISQGs revealed the absence of pollution for all the stations (Table 4). For Malaysian studies, the concentration ranges of all of the heavy metals in the present study revealed higher concentration than the range of the Langat River, Terengganu River and Kelantan River.

Table 4. Comparison of observed result with sediment guidelines and previous study.

\begin{tabular}{|c|c|c|c|c|c|c|}
\hline & \multicolumn{5}{|c|}{ Average Concentrations $(\mu \mathrm{g} / \mathrm{g})$} & \multirow[t]{2}{*}{ References } \\
\hline & $\mathbf{P b}$ & Zn & $\mathrm{Cd}$ & $\mathrm{Cu}$ & $\mathrm{Fe}(\%)$ & \\
\hline Present study (range) & $25.40-60.77$ & $21.31-160.48$ & $1.51-4.02$ & $6.60-183.52$ & $20.24-56.58$ & \\
\hline Average & 28.86 & 55.38 & 2.94 & 24.67 & 35.07 & \\
\hline \multicolumn{7}{|l|}{ Regional studies } \\
\hline DRS River, China & 25.2 & 72.5 & 0.29 & 24.6 & 3.65 & [48] \\
\hline Red Sea, Egypt & $5.0-56$ & - & $0.65-5.75$ & $6.8-190.2$ & - & [49] \\
\hline Tamagawa River, Japan & 14.4 & 72.7 & 0.15 & 28.77 & 4.01 & {$[50]$} \\
\hline \multicolumn{7}{|l|}{ Malaysian studies } \\
\hline Langat River & $5.57-55.71$ & $12.26-74.70$ & - & $2.24-14.84$ & - & [19] \\
\hline Terengganu River & - & 71.27 & - & 15.01 & 2.437 & [51] \\
\hline Kelantan River & 20.82 & 18.67 & 1.82 & - & 3.86 & {$[52]$} \\
\hline \multicolumn{7}{|l|}{ Sediment Guidelines } \\
\hline Continental crust value & 14.8 & 65 & 0.098 & 25 & 3.49 & [53] \\
\hline USEPA & 35.8 & 121 & 0.99 & 31.6 & - & [47] \\
\hline ISQG & 35 & 123 & - & 35.7 & - & [54] \\
\hline
\end{tabular}


This comparative data strongly indicated that among various river of Malaysia the Perak river pollution is most alarming and some of the heavy metal concentrations have already exceeded and some of them are very close to the standard maximum limit.

\section{Conclusions}

Geostatistical analysis of heavy metals $(\mathrm{Pb}, \mathrm{Cd}, \mathrm{Cu}, \mathrm{Zn}$ and $\mathrm{Fe})$ in sediments from 15 sampling stations showed that concentration of target heavy metals varied in the order of $\mathrm{Fe}>\mathrm{Zn}>\mathrm{Pb}>\mathrm{Cu}>$ $\mathrm{Cd}$. The enrichment value for the studied metals was in the order of $\mathrm{Cd}>\mathrm{Pb}>\mathrm{Zn}>\mathrm{Cu}$, whereas the geoaccumulation index (Igeo) results were in the order of $\mathrm{Cd}>\mathrm{Fe}>\mathrm{Pb}>\mathrm{Zn}>\mathrm{Cu}$. The values of PLI were found to be generally high $(>1)$ in all the studied stations. Both the SQG and ETQ indicated that the downstream region is more polluted than the upstream region. From the source analysis it is clear that $\mathrm{Pb}, \mathrm{Zn}$ and $\mathrm{Cu}$ concentrations are mainly due to natural sources whereas anthropogenic activities contribute to the higher concentration of Fe and $\mathrm{Cd}$. Based on the findings of this study, we suggest that the urban wastewater and the effluents emerging from industries must be monitored periodically for maintaining the standards prescribed by the pollution control board for various industries in the region. Furthermore, treatment of industrial effluents, particularly from textile mills, electroplating/galvanising, lead reprocessing, tanning and chemical industries, before discharging in the upper catchment is a prerequisite for controlling the level of pollution in the river. The limitation of this study was that the sample was collected at summer season only and for clear understanding of the river pollution status a seasonal variation could have maintained.

Supplementary Materials: The following are available online at http://www.mdpi.com/2306-5338/6/2/30/s1.

Author Contributions: Conceptualization, M.A.S. and S.C.P.; Methodology, R.B.A., and W.R.K.; Formal Analysis and Investigation, F.I.S, and A.E.R.; Writing-Initial Drafting, F.I.S., and M.A.S.; Writing-Review and Editing, S.C.P. and M.A.S.; Visualization, S.C.P.; Supervision, M.A.S.

Funding: There was no funding for this research work.

Acknowledgments: This work was conducted at the faculty of Earth Science, University Malaysia Kelantan under student research work. The authors would like to thank Forest Biotechnology Division Laboratory of Forest Research Institute of Malaysia for providing logistics and analytical supports. Authors also like to thank Talib Latif, University of Kebangsaan, Malaysia for his valuable review comments. This research work was conducted without any financial support from any sources.

Conflicts of Interest: The authors declare no conflict of interest.

\section{References}

1. Duman, F.; Aksoy, A.; Demirezen, D. Seasonal variability of heavy metals in surface sediment of Lake Sapanca, Turkey. Environ. Monit. Assess. 2007, 133, 277-283. [CrossRef] [PubMed]

2. Batayneh, A.T. Toxic (aluminum, beryllium, boron, chromium and zinc) in groundwater: Health risk assessment. Int. J. Environ. Sci. Technol. 2012, 9, 153-162. [CrossRef]

3. Yi, Y.; Tang, C.; Yi, T.; Yang, Z.; Zhang, S. Health risk assessment of heavy metals in fish and accumulation patterns in food web in the upper Yangtze River. China. Ecotoxicol. Environ. Saf. 2017, 145, $295-302$. [CrossRef]

4. Okoro, K.K.; Adeyinkam, A.; Jondikom, O.E.; Ximbam, B.J.; Kakalanga, S.J. Assesment of heavy metals contamination in groundwater: A case study of central industrial district in Ilorin, Kwara State, Nigeria. Int. J. Phys. Sci. 2012, 7, 5078-5088.

5. Zhang, X.; Li, Z.; Takeuchi, N.; Wang, F.; Wang, S.; You, X.; Zhou, P. Heavy metal-polluted aerosols collected at a rural site, Northwest China. J. Earth Sci. 2017, 28, 535-544. [CrossRef]

6. Naja, G.M.; Volesky, B. Metals in the Environment: Toxicity and Sources. In Handbook on Heavy Metals in the Environment; Wang, L.K., Chen, J.P., Hung, Y.T., Shammas, N.K., Eds.; Taylor \& Francis and CRC Press: Boca Raton, FL, USA, 2009; pp. 13-61.

7. Schertzinger, G.; Ruchter, N.; Sures, B. Metal accumulation in sediments and amphipods downstream of combined sewer overflows. Sci. Total Environ. 2018, 616-617, 1199-1207. [CrossRef] [PubMed] 
8. Combest, K.B. Trace Metals in Sediment: Spatial Trends and Sorption Processes. J. Am. Water Resour. Assoc. 1991, 27, 19-28. [CrossRef]

9. Chakraborty, P.; Sarkar, A.; Vudamala, K.; Naik, R.; Nath, B.N. Organic matter: A key factor in controlling mercury distribution in estuarine sediment. Mar. Chem. 2014, 173, 302-309. [CrossRef]

10. Ong, M.C.; Kamaruzzaman, B.Y.; Noor Azhar, M.S. Sediment characteristic studies in the surface sediment from Kemaman mangrove forest, Terengganu, Malaysia. Orient. J. Chem. 2012, 28, 1639-1644. [CrossRef]

11. Rahmanian, N.; Hajar, S.; Ali, B.; Homayoonfard, M.; Ali, N.J.; Rehan, M.; Nizami, A.S. Analysis of Physiochemical Parameters to Evaluate the Drinking Water Quality in the State of Perak, Malaysia. J. Chem. 2015, 2015, 716125. [CrossRef]

12. Lee, C. Infrastructure and economic development. In Malaysia: Policies and Issues in Economic Development; Mahani, Z., Ed.; Institute of Strategic and International Studies (ISIS): Kuala Lumpur, Malaysia, 2011; pp. 423-436.

13. Muyibi, S.A.; Ambali, A.R.; Eissa, G.S. The Impact of Economic Development on Water Pollution: Trends and Policy Actions in Malaysia. Water Resour. Manag. 2008, 22, 485-508. [CrossRef]

14. Hossain, M.A.; Ali, N.M.; Islam, M.S.; Hossain, H.M.Z. Spatial distribution and source apportionment of heavy metals in soils of Gebeng industrial city, Malaysia. Environ. Earth Sci. 2014, 73, 115-126. [CrossRef]

15. Heiri, O.; Lotter, A.F.; Lemcke, G. Loss on ignition as a method for estimating organic and carbonate content in sediments: reproducibility and comparability of results. J. Paleolimnol. 2011, 25, 101-110. [CrossRef]

16. Bengtsson, L.; Enell, M. Chemical analysis. In Handbook of Holocene Palaeoecology and Palaeohydrology; Berglund, B.E., Ed.; Wiley: Chichester, UK, 1986; pp. 423-445.

17. U.S. EPA. Method 3050B: Acid Digestion of Sediments, Sludges, and Soils; Revision 2; U.S. EPA: Washington, DC, USA, 1996. Available online: https://www.epa.gov/homeland-security-research/epa-method-3050b-aciddigestion-sediments-sludges-and-soils (accessed on 19 March 2018).

18. Islam, M.S.; Ahmed, M.K.; Raknuzzaman, M.; Habibullah-Al-Mamun, M.; Masunaga, S. Metal Speciation in Sediment and Their Bioaccumulation in Fish Species of Three Urban Rivers in Bangladesh. Arch. Environ. Contam. Toxicol. 2014, 68, 92-106. [CrossRef]

19. Lim, W.Y.; Aris, A.Z.; Ismail, T.H.T. Spatial Geochemical Distribution and Sources of Heavy Metals in the Sediment of Langat River, Western Peninsular Malaysia. Environ. Forensics 2014, 14, 133-145. [CrossRef]

20. Bhuiyan, M.A.H.; Parvez, L.; Islam, M.A.; Dampare, S.B.; Suzuki, S. Heavy metal pollution of coal mine-affected agricultural soils in the northern part of Bangladesh. J. Hazard. Mater. 2010, 173, 384-392. [CrossRef] [PubMed]

21. Müller, V.G. Schadstoffe in sedimenten-Sedimenteals Schadstoffe. Mitt. Österr. Geol. Ges. 1986, 79, $107-126$.

22. Turekian, K.K.; Wedepohl, K.H. Distribution of the elements in some major units of the earth's crust. Geol. Soc. Am. Bull. 1961, 72, 175-192. [CrossRef]

23. Tomlinson, D.L.; Wilson, J.G.; Harris, C.R.; Jeffrey, D.W. Problems in the assessment of heavy-metal levels in estuaries and the formation of a pollution index. Helgoländer Meeresuntersuchungen 1980, 33, 566-575. [CrossRef]

24. Hinkey, L.M.; Zaidi, B.R. Differences in SEM-AVS and ERM-ERL predictions of sediment impacts from metals in two US Virgin Islands marinas. Mar. Pollut. Bull. 2007, 54, 180-185. [CrossRef]

25. Violintzis, C.; Arditsoglou, A.; Voutsa, D. Elemental composition of suspended particulate matter and sediments in the coastal environment of Thermaikos Bay, Greece: delineating the impact of inland waters and wastewaters. J. Hazard. Mater. 2009, 166, 1250-1260. [CrossRef]

26. ANZECC, 2000. Australian and New Zealand Guidelines for Fresh and Marine Water Quality. Available online: http:/ / www.agriculture.gov.au/SiteCollectionDocuments/water/nwqms-guidelines-4-vol1.pdf (accessed on 18 March 2018).

27. Smith, S.L.; MacDonald, D.D.; Keenleyside, K.A.; Ingersoll, C.G.; Field, L.J. A preliminary evaluation of sediment quality assessment values for freshwater ecosystems. J. Great Lakes Res. 1996, 22, 624-638. [CrossRef]

28. Long, E.R.; Macdonald, D.D. Recommended Uses of Empirically Derived, Sediment Quality Guidelines for Marine and Estuarine Ecosystems. Hum. Ecol. Risk Assess. 1998, 4, 1019-1039. [CrossRef]

29. Mccready, S.; Birch, G.F.; Long, E.R. Metallic and organic contaminants in sediments of Sydney Harbour, Australia and vicinity-A chemical dataset for evaluating sediment quality guidelines. Environ. Int. 2006, 32, 455-465. [CrossRef] 
30. Ali, A.E.; Strezov, V.; Davies, P.J.; Wright, I. River sediment quality assessment using sediment quality indices for the Sydney basin, Australia affected by coal and coal seam seam gas mining. Sci. Total Environ. 2018, 616-617, 695-702. [CrossRef]

31. ASTDR, 2015. The Priority List of Hazardous Substances. Available online: http://www.atsdr.cdc.gov/spl/ (accessed on 18 March 2018).

32. Mohiuddin, K.M.; Zakir, H.M.; Otomo, K.; Sharmin, S.; Shikazono, N. Geochemical distribution of trace metal pollutants in water and sediments of downstream of an urban river. Int. J. Environ. Sci. Technol. 2009, 7, 17-28. [CrossRef]

33. Laskov, C.; Amelung, W.; Peiffer, S. Organic Matter Preservation in the Sediment of an Acidic Mining Lake. Environ. Sci. Technol. 2002, 36, 4218-4223. [CrossRef]

34. Ma, X.; Zuo, H.; Tian, M.; Zhang, L.; Meng, J.; Zhou, X.; Min, N.; Chang, X.; Liu, Y. Assessment of heavy metals contamination in sediments from three adjacent regions of the Yellow River using metal chemical fractions and multivariate analysis techniques. Chemosphere 2016, 144, 264-272. [CrossRef]

35. Shafie, N.A.; Aris, A.Z.; Haris, H. Geoaccumulation and distribution of heavy metals in the urban river sediment. Int. J. Sediment Res. 2014, 29, 368-377. [CrossRef]

36. Peng, J.; Yong-Hui, S.; Peng, Y.; Cui, X.; Guang-Lei, Q. The remediation of heavy metals contaminated sediment. J. Hazard. Mater. 2009, 161, 633-640. [CrossRef]

37. Raju, N.J.; Shukla, U.K.; Ram, P. Hydrogeochemistry for the assessment of groundwater quality in Varanasi: A fast-urbanizing center in Uttar Pradesh, India. Environ. Monit. Assess. 2011, 173, 279-300. [CrossRef]

38. Adamo, P.; Arienzo, M.; Imperato, M.; Naimo, D.; Nardi, G.; Stanzione, D. Distribution and partition of heavy metals in surface and sub-surface sediments of Naples city port. Chemosphere 2005, 61, 800-809. [CrossRef]

39. Birth, G. A scheme for assessing human impacts on coastal aquatic environments using sediments. In Coastal GIS; Woodcoffe, C.D., Furness, R.A., Eds.; Wollongong University Papers in Center for Maritime Policy, 14; Wollongong University: Wollongong, Australia, 2014.

40. Chen, C.W.; Kao, C.M.; Chen, C.F.; Dong, C.D. Distribution and accumulation of heavy metals in the sediments of Kaohsiung Harbor, Taiwan. Chemosphere 2007, 66, 1431-1440. [CrossRef]

41. Håkanson, L. An ecological risk index for aquatic pollution control. a sedimentological approach. Water Res. 2007, 14, 975-1001. [CrossRef]

42. Harikumar, P.; Nasir, U.; Rahman, M.M. Distribution of heavy metals in the core sediments of a tropical wetland system. Int. J. Environ. Sci. Technol. 2009, 6, 225-232. [CrossRef]

43. Praveena, M.S.; Radojevic, M.; Abdullah, M.H. The assessment of mangrove sediment quality in Mengkabong Lagoon: An index analysis approach. Int. J. Environ. Sci. Educ. 2007, 2, 60-68.

44. Wu, B.; Wang, G.; Wu, J.; Fu, Q.; Liu, C. Sources of Heavy Metals in Surface Sediments and an Ecological Risk Assessment from Two Adjacent Plateau Reservoirs. PLoS ONE 2014, 9, e102101. [CrossRef]

45. Zhai, M.; Kampunzu, H.A.B.; Modisi, M.P.; Totolo, O. Distribution of heavy metals in Gaborone urban soils (Botswana) and its relationship to soil pollution and bedrock composition. Environ. Geol. 2003, 45, 171-180. [CrossRef]

46. DOE, Department of Environment. A Handbook for Environmental Impact Assessment Guidelines, 2nd ed.; Ministry of Science, Technology and the Environment: Prang Besar, Malaysia, 1995.

47. USEPA. Science Policy Council Handbook: Peer Review, 3rd ed.; Office of Science Policy, Office of Research and Development: Washington, DC, USA, 2006; EPA/100/B06/002. Available online: http:/ /www.epa.gov/ spc/2peerrev.htm (accessed on 18 March 2018).

48. Lin, C.; He, M.; Liu, X.; Guo, W.; Liu, S. Distribution and contamination assessment of toxic trace elements in sediment of the Daliao River System, China. Environ. Earth Sci. 2013, 70, 3163-3173. [CrossRef]

49. El-Said, G.F.; Youssef, D.H. Ecotoxicological impact assessment of some heavy metals and their distribution in some fractions of mangrove sedimentsfrom Red Sea, Egypt. Environ. Monit. Assess. 2013, 185, 393-404. [CrossRef]

50. Shikazono, N.; Tatewaki, K.; Mohiuddin, K.M.; Nakano, T.; Zakir, H.M. Sources, spatial variation, and speciation of heavy metals in sediments of the Tamagawa River in Central Japan. Environ. Geochem. Health 2012, 34, 13-26. [CrossRef]

51. Sultan, K.; Shazili, N.A.; Peiffer, S. Distribution of $\mathrm{Pb}, \mathrm{As}, \mathrm{Cd}, \mathrm{Sn}$ and $\mathrm{Hg}$ in soil, sediment and surface water of the tropical river watershed, Terengganu (Malaysia). J. Hydro-Environ. Res. 2011, 5, 169-176. [CrossRef] 
52. Ahmad, A.K.; Idris, M.; Shuhaimi-Othman, M. Water Quality and Heavy Metal Concentrations in Sediment of Sungai Kelantan, Kelantan, Malaysia: A Baseline Study. Sains Malays. 2009, 38, 435-442.

53. Wedepohl, K.H. The composition of the continental crust. Geochim. Cosmochim. Acta 1995, 59, 1217-1232. [CrossRef]

54. Canadian Council of Ministers of the Environment. Canadian sediment quality guidelines for the protection of aquatic life: Summary Tables. Updated. In Canadian Environmental Quality Guidelines, 1999; Canadian Council of Ministers of the Environment: Winnipeg, MB, Canada, 2001.

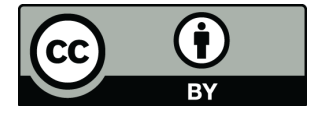

(C) 2019 by the authors. Licensee MDPI, Basel, Switzerland. This article is an open access article distributed under the terms and conditions of the Creative Commons Attribution (CC BY) license (http:/ / creativecommons.org/licenses/by/4.0/). 